\title{
Evaluation of Effective Weed Management Strategy for Enhancing Productivity and Profitability of Chickpea (Cicer arietinum L.) under Rain- fed Condition of Southern Rajasthan
}

\author{
Hargilas* \\ Agricultural Research Station (MPUAT), Borwat farm, Dahod Road, Banswara-327001, \\ Rajasthan, India \\ *Corresponding author
}

\begin{tabular}{l} 
K e y w o r d s \\
$\begin{array}{l}\text { Chickpea, Weed } \\
\text { Control efficiency, } \\
\text { Herbicides, B: C } \\
\text { ratio }\end{array}$ \\
\hline Article Info \\
$\begin{array}{l}\text { Accepted: } \\
07 \text { October } 2018 \\
\text { Available Online: } \\
10 \text { November } 2018\end{array}$
\end{tabular}

A field experiment was conducted during Rabi season of 2016-17 and 2017-18 at Agricultural Research Station, Banswara (Rajasthan) to evaluate the effective weed management strategy for enhancing productivity and profitability of chickpea. The experiment consisted of eleven treatments of PE (pendimethalin 30EC, pendimethalin 38.7CS, sulfentrazone 39.6 SC, imazethapyr 2\%) and POE (fenoxaprop ethyl $9.3 \mathrm{EC}$ ) herbicides with weed free and weedy check was laid out in random block design with three replications. Results revealed that the sequential weed management practices of pendimethalin 38.7CS@1.0kg a.i. ha ${ }^{-1}$ used as pre-emergence followed by one hand weeding at 30-35 DAS has resulted the lower weed dry weight $\left(12.13 \mathrm{~g} \mathrm{~m}^{-2}\right)$ with higher weed control efficiency $(81.86 \%)$ than other herbicidal treatments, which ultimately increased seed yield $\left(1968 \mathrm{~kg} \mathrm{ha}^{-1}\right)$, net return (Rs $\left.52600 \mathrm{ha}^{-1}\right)$ and B: C ratio (2.01). The highest seed yield $\left(2000 \mathrm{~kg} \mathrm{ha}^{-1}\right)$ and weed control efficiency $(95.87 \%)$ recorded in weedy free with two hand weeding at 30-35 and 60-65DAS. It can be concluded that preemergence application of pendimethalin 38.7CS@1.0kg a.i. ha ${ }^{-1}+$ one hand weeding at 3035 DAS proved to include as effective and economical weed management practice in chickpea under rain-fed condition of southern Rajasthan.

\section{Introduction}

Chickpea is the premier pulse crop of India, shared about $70 \%$ area and $67 \%$ production of the world. In last 4 decade the area, production and productivity fluctuated widely. The area of chickpea is shifted from north India to central and southern India due to development of short duration genotypes which are better adapted to warmer, short-season environment, like central and southern Indian. Rajasthan is major part of north and central India that contributed about $15.37 \%$ area and $14.47 \%$ production of chickpea in India, but productivity of chickpea $\left(888 \mathrm{~kg} \mathrm{ha}^{-1}\right)$ is recorded lower than national level (937 $\left.\mathrm{kg} \mathrm{ha}{ }^{-1}\right)$. The productivity of chickpea has fallen due to various constraints such as biotic and abiotic factors. The major abiotic factor is low moisture stress in rain-fed area. Among, the biotic constraints wilt, dry root rot and blight and pod borer are the major constraints 
in Rajasthan. In addition to that, the weed also results in major loss in yield by competing for space, nutrients, water and light. Poor weed management is one of the most important yield limiting factors in chickpea. Weeds can remove plant nutrients from soil more efficiently than crops. Under rain-fed ecosystem, efficient water use by weeds may increase severity of drought and results in a low crop yield. Most weed species can grow faster and taller than chickpea and inhibit its growth, absorbs sunlight, and affect photosynthesis and plant productivity adversely (Rao, 2000). Weeds not only compete with crop for water, nutrient, light and space but also provide harbour for insect pests. Being slow in its early growth and short statured plant, chickpea is highly susceptible to weed competition and weeds causes up to $77.8 \%$ yield loss (Patel et al., 2006).

Weed management in chickpea is an important component for crop protection and improving the yield potential of the crop. Conventional methods of hoeing and weeding are laborious, expensive and insufficient. Moreover, weeding during critical growth stages is very difficult due to increased cost of human labours and its scarce does not prove effective for weed control due to their spectrum of weed control. Therefore, present study was find out the appropriate combination of cultural and chemical weed management practices for weed control in chickpea, which is practically effective and economically feasible for farmers under sub-humid condition of southern Rajasthan.

\section{Materials and Methods}

A field experiment was conducted during rabi season of 2015-16 and 2016-17 at Agricultural Research Station, Banswara, Rajasthan. The soil of the experimental field was clay loam having organic carbon $0.42 \%$, available nitrogen $218 \mathrm{~kg} \mathrm{ha}^{-1}$, phosphorous $23 \mathrm{~kg} \mathrm{ha}^{-1}$ and potash $370 \mathrm{~kg} \mathrm{ha}^{-1}$ with $\mathrm{pH}$ 7.80. The experiment consisting of 11 treatments viz., pendimethalin 30EC@1.0 kg a.i ha ${ }^{-1}$ as preemergence $(\mathrm{PE})+$ one hand weeding $(\mathrm{HW})$ at 30-35 days after sowing (DAS), pendimethalin 38.7CS@1.0 kg a.i ha ${ }^{-1} \mathrm{PE}$, pendimethalin 38.7CS@1.0 kg a.i ha ${ }^{-1} \mathrm{PE}+$ one HW at 30-35 DAS, Sulfentrazone 39.6SC@0.05 kg a.i ha ${ }^{-1}$ $\mathrm{PE}+$ one hoeing at 30-35 DAS, fenoxyprop ethyl 9.3EC@60 g a.i. ha ${ }^{-1}$ at 30-35 DAS, pendimethalin 30EC+ imazethapyr 2\% EC (RM) @ $1.0 \mathrm{~kg}$ a.i. ha ${ }^{-1} \mathrm{PE}$, pendimethalin 30EC+imazethapyr 2\% EC(RM)@1.0 kg ha ${ }^{-1}$ $\mathrm{PE}+$ one weeding at 30-35DAS, pendimethalin $30 \mathrm{EC}+$ imazethapyr $2 \%$ EC(TM)@1.0 kg ha ${ }^{-1} \mathrm{PE}+$ one weeding at 3035DAS, one hand weeding at 30-35DAS, two hand weedings at 30-35 and 60-65DAS and weedy checks. The experiment was laid out in randomized block design with three replications. After thorough preparation of land the chickpea seed treated with Rhizobium, phosphate solubilizing bacteria and Trichoderma was sown on first mid of October during different seasons by adopting the spacing of $30 \times 10 \mathrm{~cm}$. Before sowing, entire dose of nitrogen $\left(20 \mathrm{~kg} \mathrm{ha}^{-1}\right)$ and phosphorus $\left(40 \mathrm{~kg} \mathrm{ha}^{-1}\right)$ was applied as basal as per the recommendations. The pre and post emergence herbicide treatments were imposed as per schedule during October and November months, respectively. There were no major pests and diseases during all the two years of experimentation. Weed density and weed dry weight was recorded at 90DAS. The data on dry weight were subjected to arcsine transformation before statistical analysis to normalize their distribution. Data for individual years were pooled and statistically analyzed as per the procedure given by Gomez and Gomez (1984) for randomized block design. Weed control efficiency (WCE) was calculated by weed control efficiency (WCE), weed control index (WCI), herbicide efficiency index (HEI) and weed index (WI) were calculated by the following formula. 
$W C E(\%)=\frac{W D_{c}-W D_{T}}{W D_{c}} \times 100$

Where,

$\mathrm{WD}_{\mathrm{C}}=$ Weed density in control plot

$\mathrm{WD}_{\mathrm{T}}=$ Weed density in treated plot

$W C I(\%)=\frac{W_{C M}-W D M M_{T}}{W D D M_{C}} \times 100$

Whereas

$\mathrm{WDM}_{\mathrm{C}}=$ Weed dry matter weight in control plot

$\mathrm{WDM}_{\mathrm{T}}=$ Weed dry matter weight in treated plot

Weed index $(\%)=\frac{\mathrm{Y}_{\mathrm{F}}-\mathrm{Y}_{\mathrm{T}}}{\mathrm{Y}_{\mathrm{F}}} \times 100$

Whereas

$\mathrm{W}_{\mathrm{T}}=$ Seed yield in weed free plot

$\mathrm{W}_{\mathrm{C}}=$ Seed yield in weed treated plot

Herbicide efficiency index $(H E I)=\frac{\frac{Y_{T}-Y_{C}}{Y_{T}} \times 100}{\frac{W D M_{T}}{W D M_{C}} \times 100}$

Whereas

$\mathrm{Y}_{\mathrm{T}}=$ Seed yield in treated plot

$\mathrm{W}_{\mathrm{C}}=$ Seed yield in control plot

$\mathrm{WDM}_{\mathrm{T}}=$ Weed dry matter in treated plot

$\mathrm{WDM}_{\mathrm{C}}=$ Weed dry matter in control plot

\section{Recording observations of data}

Regarding agronomic characters, ten competitive plants were randomly selected from each plot and observations were recorded for growth and yield attributes. Whereas, seed yield obtained from the net plot area was recorded at physiological maturity and expressed in $\mathrm{kg} \mathrm{ha}^{-1}$. For economic study, prevailing market price was used for different outputs and inputs. The similar trend of results was observed during 2016-17 and 2017-18 for all the characters. Hence, the pooled analysis was done for the results and discussion.

\section{Results and Discussion}

\section{Weed flora}

The dominant weed flora of the experimental plots included Chenopodium album, Chenopodium murale, Convolvulus arvensis, Anagallis arvensis, Melilotus indica, Ameranthus viridis, Physalis minima, Parthenium hysteroiphorous, Portulaca oleracea, Euphorbia hirta, among broadleaf weeds, Cynodon dactylon, panicum spp among grasses, Cyperus rotundus among sedges. All the weed control treatments showed significant reduction in weed density and weed dry matter weight as compared weedy check at all stages during both the years (Table 1). Treatments of herbicides with hand weeding were significantly superior over to alone application of herbicides in reducing weed density. Significantly lowest weed density $\left(1.21 \mathrm{~m}^{-2}\right)$ and weed dry matter weight $\left(3.89 \mathrm{~g} \mathrm{~m}^{-2}\right)$ and highest weed control efficiency $(95.38 \%)$ recorded in weed free plot. The highest weed density $\left(29.17 \mathrm{~m}^{-2}\right)$ and weed dry weight $\left(84 \mathrm{~g} \mathrm{~m}^{-2}\right)$ and lowest weed control efficiency recorded in weedy check.

Among the herbicidal treatments, pendimethalin 38.7SC@1.0 kg a.i. $\mathrm{ha}^{-1}$ PE+HW at 30-35DAS obtained lowest weed density $\left(6.38 \mathrm{~m}^{-2}\right)$ and weed dry matter $\left(15.21 \mathrm{~g} \mathrm{~m}^{-2}\right)$ and highest WCE (81.70\%) which found at par with application of pendimethalin 30EC+ imazethapyr 2\% (RM) @ $1.0 \mathrm{~kg} \mathrm{ha}^{-1} \mathrm{PE}+\mathrm{HW}$ at 30-35DAS and recorded significantly superior over rest expect pendimethalin 30EC@1.0kg a.i./ha 
$+\mathrm{HW}$ at 30-35 DAS in the case of weed density. The similar results reported by Rathod et al., (2017).

The data of weed control index, weed index and herbicide efficiency index showed significant (Table 1). Highest weed control index $(96.21 \%)$ obtained with weed free plot which was recorded significantly superior over rest treatments. Among herbicidal treatments, pendimethalin 38.7 CS@1.00kg a.i/ha $\mathrm{PE}+\mathrm{HW}$ at 30-35DAS recorded maximum weed control index (82.68\%) followed by pendimethalin 30EC + imazethapyr 2\% (RM) @ 1.0kg a.i ha ${ }^{-1}$ $\mathrm{PE}+\mathrm{HW}$ at 30-35 DAS and significantly higher over rest treatments.

Weed index $(59.31 \%)$ was significantly higher recorded with weedy check followed by fenoxaprop ethyl 9.3EC@60g a.i. ha ${ }^{-1}$ POE. Whereas, lowest weed index was recorded with weedy free followed by pendimethalin 38.7CS@1.0kg a.i. ha ${ }^{-1}+\mathrm{HW}$ at 30-35DAS and significantly lower than rest treatments.

The highest value of herbicide efficiency index (12.17) recorded in weed free plot, but among the herbicides, maximum herbicide efficiency (2.46) was recorded in pendimethalin 38.7 CS@1.0kg a.i./ha+ HW at 30-35DAS followed by pendimethalin 30EC+imazethapyr 2(RM) @ 1.0kg a.i/ha PE + HW at 30-35DAS and pendimethalin 30EC@1.0kg a.i. ha ${ }^{-1}+\mathrm{HW}$ at 30-35DAS.

All the weed indexes indicated that preemergence application of pendimethalin 78.7CS@1.0kg a.i ha ${ }^{-1}$ might be reduced the germination of total weed population during initial period of crop growth and then one hand weeding at 30-35DAS, might be sufficient to control of remaining grassy weeds and second flush of broad leaf weed. The integrated weed management by using pre-emergence application of herbicide followed by one hand weeding at 30-35 DAS was reported effective weed management practice by Pedde et al., (2013).

\section{Growth and yield parameters}

Plant height was varied significantly with different weed management treatments (Table 2). Highest plant height $(64.31 \mathrm{~cm})$ was recorded with weed free plot followed by pendimethalin 38.7CS@1.0kg a.i./ha PE+HW at 30-35 DAS and pendimethalin 30EC+imazethapyr 2 (RM) @ 1.0kg a.i. ha ${ }^{-1}$ $\mathrm{PE}+\mathrm{HW}$ at 30-35 DAS and it was found significantly superior over rest treatments. Two hand weeding at 30-35DAS and 6065DAS since no weeds were allowed to grow throughout the crop growth periods which enable zero crop-weed completion for resources throughout the crop growth period.

While, lowest plant height $(40.49 \mathrm{~cm})$ was obtained with weedy check plot. The main reason might be due to the presence of higher number weeds associated with the crop which exhibited server competition throughout the crop growth. Ratnam et al., (2011) reported that the plant height was reduced progressively under weed competition.

The treatments comprising of two hands weeding at 30-35 and 60-65DAS and herbicidal application recorded significantly more number of branches than weedy check (Table 2). Maximum number of branches was recorded in two hand weeding (11.33 branches plant $^{-1}$ ) followed by pendimethalin 38.7CS@ $1.0 \mathrm{~kg}$ a.i $\mathrm{ha}^{-1} \mathrm{PE}+\mathrm{HW}$ at 30-35 DAS. However, it was recorded significantly superior rest treatments. Similarly, all weed control treatments were significantly superior to weedy check in influencing number of pods per plant. Maximum number of pods (63.17 plant $^{-1}$ ) was recorded under two HW at 30-35 and 60-65 DAS that found significantly superior over rest treatments. 
Table.1 Effect of weed management practices on weed density, weed dry matter, weed control efficiency, weed control index, weed index, herbicidal efficiency index at harvest (pooled over 2 year)

\begin{tabular}{|c|c|c|c|c|c|c|}
\hline Treatment & $\begin{array}{l}\text { Weed density } \\
\left(\text { weeds } \mathbf{m}^{-2} \text { ) }\right.\end{array}$ & $\begin{array}{c}\text { Weed dry } \\
\text { matter }\left(\mathrm{g} \mathrm{m}^{-2}\right)\end{array}$ & $\begin{array}{l}\text { WCE } \\
(\%)\end{array}$ & WCI $(\%)$ & WI $(\%)$ & HEI $(\%)$ \\
\hline T: Pendi.30EC @1.0kg a.i. ha ${ }^{-1}$ PE+one HW & 8.41 & 26.83 & 71.19 & 68.79 & 18.19 & 1.18 \\
\hline $\mathrm{T}_{2}$ : Pendi. 38.7 CS @1.0kg a.i. ha ${ }^{-1} \mathrm{PE}$ & 14.43 & 45.22 & 50.46 & 46.79 & 40.39 & 0.40 \\
\hline $\mathrm{T}_{3}$ : Pendi. 38.7 CS @1.0kg a.i. ha ${ }^{-1}$ PE+ HW & 6.38 & 15.21 & 77.86 & 82.68 & 6.47 & 2.46 \\
\hline $\begin{array}{c}\mathrm{T}_{4}: \text { Sulfenotrazon } 39.6 \mathrm{EC} @ 50 \mathrm{~g} \text { a.i.ha }{ }^{-1} \mathrm{PE}+ \\
\text { HW }\end{array}$ & 15.57 & 49.46 & 46.12 & 41.73 & 36.92 & 0.29 \\
\hline $\begin{array}{c}\mathrm{T}_{5} \text { : Fenoxaprop ethyl } 9.3 \text { EC @60g a.i. } \text { ha }^{-1} \\
\text { POE }\end{array}$ & 14.64 & 47.11 & 49.71 & 44.53 & 52.99 & 0.17 \\
\hline $\begin{array}{c}\mathrm{T}_{6}: \text { Pendi.30EC+Imaze.2\% (RM) @ 1.0kg } \\
\text { a.i.ha }{ }^{-1} \text { PE }\end{array}$ & 10.45 & 33.62 & 63.57 & 60.66 & 25.48 & 0.81 \\
\hline $\begin{array}{c}\mathrm{T}_{7}: \text { Pendi.30EC+Imaze.2\% (RM)@ 1.0kg } \\
\text { a.i.ha }^{-1} \text { PE+ HW }\end{array}$ & 6.94 & 17.86 & 79.72 & 79.50 & 16.98 & 1.84 \\
\hline $\begin{array}{c}\mathrm{T}_{8} \text { : Pendi.30 EC+Imaze.2\% (Tank mix.)@ } \\
\text { 1.0kg a.i.ha }{ }^{-1} \text { PE + HW }\end{array}$ & 12.96 & 41.11 & 55.40 & 51.70 & 37.95 & 0.44 \\
\hline $\mathrm{T}_{9:}$ One HW at 30-35 DAS & 10.61 & 35.05 & 63.00 & 58.96 & 26.83 & 0.75 \\
\hline $\begin{array}{c}\mathrm{T}_{10 .} \text { Weed free (Two HW at 30-35 \& 60-65 } \\
\text { DAS) }\end{array}$ & 1.21 & 3.89 & 95.87 & 96.21 & 0.00 & 12.17 \\
\hline$T_{11 .}$ Weedy check & 29.17 & 84.35 & 0.00 & 0.00 & 59.31 & 0.00 \\
\hline $\mathrm{CD}(\mathrm{P}=0.05)$ & 2.73 & 7.49 & 8.54 & 13.52 & 15.31 & 3.43 \\
\hline
\end{tabular}


Table.2 Effect of weed management practices on plant growth, yield attributes and yield (pooled data of 2 year)

\begin{tabular}{|c|c|c|c|c|c|c|c|}
\hline Treatment & $\begin{array}{l}\text { Plant } \\
\text { height } \\
\text { (cm) }\end{array}$ & $\begin{array}{c}\text { Pods } \\
\text { plant }^{-1}\end{array}$ & $\begin{array}{l}\text { Branche } \\
\text { s plant }^{-1}\end{array}$ & $\begin{array}{c}100 \text { seed } \\
\text { weight(g) }\end{array}$ & $\begin{array}{l}\text { Seed } \\
\text { yield (kg } \\
\left.\text { ha }^{-1}\right)\end{array}$ & $\begin{array}{l}\text { Stover } \\
\text { yield } \\
\left(\mathrm{kg} \mathrm{ha}^{-1}\right)\end{array}$ & $\begin{array}{l}\text { Biological } \\
\text { yield } \\
\left(\mathrm{kg} \mathrm{ha}^{-1}\right)\end{array}$ \\
\hline T: Pendi. 30EC @1.0kg a.i. ha ${ }^{-1}$ PE+one HW & 56.18 & 54.67 & 9.13 & 20.87 & 1610 & 2406 & 4010 \\
\hline $\mathrm{T}_{2}$ : Pendi. 38.7 CS @1.0kg a.i. ha ${ }^{-1}$ PE & 44.60 & 45.53 & 5.40 & 18.93 & 1265 & 1940 & 3234 \\
\hline T : Pendi. 38.7 CS @1.0kg a.i. ha $^{-1}$ PE+ HW & 62.43 & 57.90 & 10.33 & 21.53 & 1968 & 3100 & 5167 \\
\hline $\mathrm{T}_{4}$ :Sulfenotrazon 39.6 EC @50g a.i.ha ${ }^{-1}$ PE+ HW & 45.60 & 47.67 & 6.33 & 18.85 & 1149 & 1669 & 2782 \\
\hline $\mathrm{T}_{5}$ : Fenoxaprop ethyl 9.3 EC @60g a.i. ha ${ }^{-1}$ POE & 45.07 & 41.00 & 6.40 & 19.18 & 1309 & 1976 & 3294 \\
\hline $\begin{array}{c}\mathrm{T}_{6}: \text { Pendi.30EC+Imaze.2\% (RM) @ 1.0kg a.i.ha } \\
\text { PE }\end{array}$ & 54.20 & 50.33 & 8.67 & 19.63 & 1204 & 1751 & 2918 \\
\hline $\begin{array}{c}\mathrm{T}_{7}: \text { Pendi.30EC+Imaze.2\% (RM)@ 1.0kg a.i.ha }{ }^{-1} \\
\text { PE+HW }\end{array}$ & 60.02 & 57.27 & 9.53 & 21.13 & 1775 & 2816 & 4693 \\
\hline $\begin{array}{c}\mathrm{T}_{8} \text { : Pendi.30 EC+Imaze.2\% (Tank mix.)@ 1.0kg } \\
\text { a.i.ha }{ }^{-1} \text { PE + HW }\end{array}$ & 45.59 & 52.37 & 7.47 & 19.27 & 1404 & 2544 & 4241 \\
\hline $\mathrm{T}_{9:}$ One HW at 30-35 DAS & 46.20 & 46.33 & 8.20 & 21.00 & 1325 & 1851 & 3086 \\
\hline$T_{10 .}$ Weed free (Two HW at 30-35 \& 60-65 DAS) & 64.31 & 63.17 & 11.33 & 21.73 & 2000 & 3286 & 5477 \\
\hline$T_{11 .}$ Weedy check & 40.49 & 29.00 & 3.53 & 18.17 & 747 & 1366 & 2278 \\
\hline $\mathrm{CD}(\mathrm{P}=0.05)$ & 4.33 & 4.91 & 1.54 & 1.168 & 199 & 371 & 478 \\
\hline
\end{tabular}


Table.3 Effect of weed management practices on economics of chickpea (pooled data of 2 year)

\begin{tabular}{|c|c|c|c|c|}
\hline Treatment & $\begin{array}{l}\text { Cost of } \\
\text { cultivation } \\
\left(\operatorname{Rs~ha} \mathbf{~}^{-1}\right)\end{array}$ & $\begin{array}{l}\text { Gross } \\
\text { return } \\
\left(\mathbf{R s ~ h a}^{-1}\right)\end{array}$ & $\begin{array}{l}\text { Net return } \\
\left(\mathrm{Rs} \mathrm{ha}^{-1}\right)\end{array}$ & B:C ratio \\
\hline T : Pendi. 30EC @1.0kg a.i. ha ${ }^{-1}$ PE+one HW & 25744 & 64389 & 38645 & 1.50 \\
\hline $\mathrm{T}_{2}$ : Pendi.38.7 CS @1.0kg a.i. ha ${ }^{-1}$ PE & 19988 & 50596 & 30608 & 1.53 \\
\hline $\mathrm{T}_{3}$ : Pendi. 38.7 CS @1.0kg a.i. ha ${ }^{-1}$ PE+ HW & 26138 & 78738 & 52600 & 2.01 \\
\hline $\mathrm{T}_{4}$ :Sulfenotrazon 39.6 EC @50g a.i.ha ${ }^{-1} \mathrm{PE}+\mathrm{HW}$ & 26654 & 45945 & 19291 & 0.72 \\
\hline T : Fenoxaprop ethyl 9.3 EC @60g a.i. ha ${ }^{-1}$ POE & 19974 & 52363 & 32389 & 1.62 \\
\hline $\mathrm{T}_{6}$ : Pendi.30EC+Imaze.2\% (RM) @ 1.0kg a.i.ha ${ }^{-1} \mathrm{PE}$ & 19974 & 48155 & 28181 & 1.41 \\
\hline $\begin{array}{c}\mathrm{T}_{7}: \text { Pendi.30EC+Imaze.2\% (RM)@ 1.0kg a.i.ha }{ }^{-1} \text { PE+ } \\
\text { HW }\end{array}$ & 26124 & 70993 & 44869 & 1.72 \\
\hline $\begin{array}{c}\mathrm{T}_{8} \text { : Pendi.30 EC+Imaze.2\% (Tank mix.)@ 1.0kg } \\
\text { a.i.ha }{ }^{-1} \text { PE + HW }\end{array}$ & 19975 & 56144 & 30019 & 1.15 \\
\hline $\mathrm{T}_{9:}$ One HW at 30-35 DAS & 24394 & 52989 & 28595 & 1.17 \\
\hline$T_{10 .}$ Weed free (Two HW at 30-35 \& 60-65 DAS) & 30544 & 80004 & 49460 & 1.62 \\
\hline$T_{11 .}$ Weedy check & 18244 & 29896 & 11652 & 0.64 \\
\hline $\mathrm{CD}(\mathrm{P}=0.05)$ & & 9758 & 7958 & 0.34 \\
\hline
\end{tabular}


Whereas, pendimethalin 38.7CS@1.0 kg a.i $\mathrm{ha}^{-1} \mathrm{PE}+\mathrm{HW}$ at 30-35 DAS was recorded nest best treatment ( 57.90 plant $^{-1}$ ) followed by pendimethalin 30EC+imazethapyr $2 \%$ (RM)@1.0kg a.i. ha ${ }^{-1}+\mathrm{HW}$ at 30-35DAS and pendimethalin 30EC @ $1.0 \mathrm{~kg}$ a.i.ha ${ }^{-1}+\mathrm{HW}$ at 30-35 DAS and significantly superior over rest treatments. The data of 100 seed weight in table 2 indicated that 100 seed weight was significantly influenced to weed management practices. The maximum 100 seed weight $(21.73 \mathrm{~g})$ was obtained in weed free plot of two hands weeding at 30-35 and 60-65DAS followed by pendimethalin 38.7CS @ 1.0kg a.i. $\mathrm{ha}^{-1}+\mathrm{HW}$ at $30-35 \mathrm{DAS}$, pendimethalin 30EC+ imazethapyr 2\% (RM) @1.0 kg a.i. $\mathrm{ha}^{-1}+$ one HW at 30-35DAS, pendimethalin 30EC @ 1.0kg a.i. ha ${ }^{-1}+\mathrm{HW}$ at 30-35 DAS and one hand weeding at 30-35DAS which recorded significantly over rest treatments. The minimum 100 seed weight $(18.17 \mathrm{~g})$ was recorded in weedy check. Overall, three treatments of weed free with two hand weeding at 30-35DAS and 60-65DAS, pendimethalin 38.7CS@1.0kg a.i. ha ${ }^{-1}$ PE followed by one hand weeding at 30-35DAS and pendimethalin 30EC+imazethapyr 2\% (RM) @ $1.0 \mathrm{~kg}$ a.i. ha ${ }^{-1}$ were significantly higher in growth and yield attributes than other weed control treatments. These treatments could be attributed to more plant height, number of branches and number of pods per plants and bold seed size due to lesser competition offered by weeds for light, water and nutrients etc., which resulted in more uptake of nutrients, water and produced more photosynthates. Similar, results have also been reported by Rathod et al., (2017).

\section{Crop productivity}

Seed yield significantly influenced with different weed control treatments (Table 2). Significantly higher seed yield was recorded in two hand weedings at 30-35 and 60-65 DAS (2000kg ha ${ }^{-1}$ mainly due to the complete elimination of weeds throughout the crop growth which enabled minimum competition and causing better plant growth along with higher number of branches and number of pods per plant and bold seed size. Among the herbicidal treatments, application of pendimethalin $38.7 \mathrm{CS} @ 1.0 \mathrm{~kg}$ a.i ha ${ }^{-1} \mathrm{PE}$ $+\mathrm{HW}$ at 30-35 DAS (1968kg ha ${ }^{-1}$ ) followed by pendimethalin 30EC+imazethapyr 2\% (RM)@1.0 kg ha ${ }^{-1} \mathrm{PE}+\mathrm{HW}$ at $30-35 \mathrm{DAS}$ $\left(1775 \mathrm{~kg} \mathrm{ha}^{-1}\right)$ recorded significantly higher seed yield as compared to other treatments. The similar trend of treatments was also observed in the production of stover and biological yield of chickpea. These three treatments were significantly out seed yielded over other weed management treatments. The high seed yield in these treatments could be attributed to more number of branches and number of pods per plants and bold seed size due to lesser competition offered by weeds for light, water and nutrients etc., which resulted in more uptake of nutrients, water and produced more photosynthates. Application of herbicides followed by hand weeding provided better environment to crop growth and development which ultimately yielded higher than either one chemical or manual weed management practice. These results are confirming with earlier work of Sharma, 2009 and Kumar et al., (2015).

\section{Economics}

Higher gross return was recorded in two hand weedings at 30-35 and 60-65 DAS (Rs. 80004 $\mathrm{ha}^{-1}$ ) followed by pendimethalin 38.7 CS@ $1.0 \mathrm{~kg}$ a.i ha ${ }^{-1} \mathrm{PE}+\mathrm{HW}$ at 30-35 DAS (Rs.78738 ha ${ }^{-1}$ ) and significantly superior over rest treatments. The higher gross returns were mainly attributed by higher seed yield, obtained due to higher weed control efficiency (Table 3). The lowest gross returns (Rs.29896 ha-1) was recorded with weedy check, which was mainly owing to less seed yield obtained due to uncontrolled weeds 
throughout the crop growth. Whereas, highest net return (Rs $52600 \mathrm{ha}^{-1}$ ) was recorded in pendimethalin 38.7CS@1.0kg a.i ha ${ }^{-1} \mathrm{PE}+$ HW at 30-35DAS followed by weed free (Rs.49460 $\mathrm{ha}^{-1}$ ) and pendimethalin $30 \mathrm{EC}+$ imazethapyr 2\% (RM) @ $1.0 \mathrm{~kg}$ a.i. ha ${ }^{-1}+\mathrm{HW}$ $\left(\right.$ Rs.44869ha $\left.{ }^{-1}\right)$. However, maximum B: C ratio (2.01) was recorded in pendimethalin 38.7CS+ HW at 30-35DAS followed by pendimethalin 30EC+ imazethapyr 2\%@1.0kg a.i./ha + HW at 30-35DAS (Rs $1.72 \mathrm{ha}^{-1}$ ) which was significantly superior over rest treatments. Because, this was resulted to get higher net return along with higher yield and weed control efficiency with lesser cost of cultivation. Minimum B: $\mathrm{C}$ ratio (0.64) was recorded in weedy check. The net return and $\mathrm{B}$ : $\mathrm{C}$ ratio were low in weed free treatment due to high cost of cultivation. These results are conformed from finding of Ratnam et al., (2011) and Pedde et al., (2013). On the basis of two years field experiment, it can be confirmed that pre-emergence application of pendimethalin 38.7 CS@ 1.0 $\mathrm{kg}$ a.i ha ${ }^{-1}+$ one hand weeding at 30-35 DAS or pendimethalin $30 \mathrm{EC}+$ imazethapyr 2\%@ $1.0 \mathrm{~kg}$ a.i $\mathrm{ha}^{-1}+$ one hand weeding at $30-35$ DAS proved superior over rest treatments with respective to effective control of weed flora, high yield and economical in chickpea crop under rain-fed condition of southern Rajasthan.

\section{References}

Gomez, K. A. and Gomez, A. A. (1984). Statistical Procedures for Agricultural Research. J. Wiley and Sons, Singapore.
Kumar, N., Hazra, K.K., Yadav, S.L. and Singh, S.S. 2015. Weed dynamics and productivity of chickpea (Cicer arietinum) under pre- and postemergence application of herbicides. Indian Journal of Agronomy, 60(4): 570-575.

Patel, B.D., Patel, V.J., Patel, J.B. and Patel, R.B. 2006. Effect of fertilizers and weed management practices on weed control in chickpea (Cicer arietinum L.) under middle Gujarat conditions. Indian Journal of Crop Science, 1(1\&2): 180183.

Pedde, K.C., Gore, A.K. and Chavan, A.S., 2013. Integrated weed management in chickpea. Indian Journal of Weed Science, 45 (4): 299.

Rao, V.S., 2000. Principles of weed science. Oxford and IBH publishing Co. Pvt. Ltd. New Delhi. p. 124.

Rathod, Pandit S., Patil, D.H. and Dodamani, B.M. 2017. Integrated weed management in chickpea (Cicer arietinum L.) under rainfed conditions of Karnataka, India. Legume Research, 40(3): 580-85

Ratnam, M. Rao, A.S. and Reddy, T.Y., 2011. Integrated Weed Management in Chickpea (Cicer arietinum L.). Indian Journal Weed Science, 43 (1\&2):70-72.

Sharma, O. L., 2009. Weed management in chickpea under irrigated conditions of western Rajasthan. Indian Journal of Weed Science, 41(3\&4): 182-184.

\section{How to cite this article:}

Hargilas. 2018. Evaluation of Effective Weed Management Strategy for Enhancing Productivity and Profitability of Chickpea (Cicer arietinum L.) under Rain-fed Condition of Southern Rajasthan. Int.J.Curr.Microbiol.App.Sci. 7(11): 472-480. doi: https://doi.org/10.20546/ijcmas.2018.711.056 